\title{
Influence of Auditor Office Size on Earnings Prediction
}

\author{
Daniel T. Lawson ${ }^{1} \&$ Robert J. Boldin ${ }^{1}$ \\ ${ }^{1}$ Indiana University of Pennsylvania, Department of Finance \& Legal Studies, Indiana, PA 15705, USA \\ Correspondence: Daniel T. Lawson, Indiana University of Pennsylvania, Department of Finance \& Legal Studies, \\ Indiana, PA 15705, USA. Tel: 1-724-357-5767 E-mail: dlawson@iup.edu
}

Received: August 22, 2014

Accepted: September 10, 2014

Online Published: September 15, 2014

doi:10.5430/afr.v3n4p31

URL: http://dx.doi.org/10.5430/afr.v3n4p31

\begin{abstract}
This paper investigates the notion that auditors from larger offices perform better and more complete audits. The central question is whether earnings audited by such auditors have better predictive value for either future earnings or for future cash flows. Evidence of a significant nonlinear relation is found for Big4 audit firms between the predictive value of both abnormal and normal accruals. Results suggest that the predictive value of both accrual components decline as office size moves from small to medium, and the predictive value increases as office size moves from medium to large. The decline may be attributed to a combination of capacity stress and excessive reputation concerns. The increase in predictive value may be related to a combination of additional independence and office level audit resources, both of which are in greater supply for larger offices than for smaller or medium sized offices.
\end{abstract}

Keywords: Audit, Auditors, Earnings Informativeness, Earnings Management, Earnings Prediction, Auditor Office Size, Human Capital, Big 4 Auditors

\section{Introduction}

Francis and $\mathrm{Yu}$ (2009) and Choi, Kim and Zang (2010) find that auditors from larger offices perform better quality audits. Specifically, clients of auditors from larger offices have lower discretionary accruals, lower probabilities of barely meeting or beating key earnings benchmarks, and higher probabilities of receiving a going concern modified audit opinion than do auditors from smaller offices. The authors use these results to suggest that auditors from larger offices do better work. Although the results are consistent, an alternative explanation may be that auditors from larger offices may be overly restrictive of management's reporting discretion. Such a condition would allow for the results found in these prior studies. The question, however, remains as to whether auditors from larger offices do better quality work which can be used in predictive tests.

Prior earnings management literature suggests that managers manipulate earnings for several reasons. One such reason is opportunistic manipulation. The literature suggests this form of discretion harms earnings quality. Another documented reason for earnings management, however, is to allow managers to communicate private information through accruals (Guay, Kothari \& Watts, 1996, and Subramanyam, 1996). This type of earnings management produces a higher quality earnings stream. If auditors from larger offices excessively constrain earnings management then earnings audited by larger offices may be less informative.

Francis and $\mathrm{Yu}$ (2009) further suggest that a more conservative earnings stream results in higher audit quality. The goal of a financial statement auditor is not just to constrain earnings management, but rather to constrain the earnings management that harms the earnings signal.

The relation between auditor office size and earnings quality can be an important characteristic of high quality earnings, i.e., the predictive value. A first measure of earnings quality is the association between earnings and future cash flows. Because audit quality literature suggests that auditors have the most influence over the discretionary component of income, earnings can be separated into (1) discretionary accruals and (2) nondiscretionary accruals including cash flows from operations. Additionally, prior literature finds that accrual based earnings are better predictors of future cash flows than current cash flows (Dechow, 1994).

This study examines the association between current earnings components and future earnings in an effort to determine the impact of auditor offices size on earnings quality. The results show that accruals both increase and decrease depending on the size of the auditor's office. Discretionary and nondiscretionary accrual data appear to be 
U-shaped in terms of the size of the auditor's office. Auditors may become less able to differentiate between opportunistic and informative accruals as the size of the office increases from small to medium. Loss of auditor judgment may be due to a combination of the auditor's excessive concerns about reputation loss and capacity stress that occurs disproportionately as office moves from small to medium sized. Auditors may also realize some counteracting benefits of greater access to local area audit expertise as the office size moves from medium to large. The remainder of the paper is organized as follows: Section II provides an overview of the literature; Section III describes the tests; Section IV presents the results and Section V summarizes the conclusions.

\section{Literature Review}

DeAngelo (1981) shows that larger audit firms perform better quality work. Larger firms have greater incentives to maintain independence from any individual client because of the larger loss to future revenues and firm profits that results from the reputation damage that follows an audit failure. Thus, larger firms have greater incentives to maintain quality than do smaller audit firms. Several studies support this result (Becker, Jiambalvo \& Subramanyam 1998; Defond and Jiambalvo, 1991; and Palmrose, 1988). Boone, Khurana and Raman (2010) also find that the second tier audit firms are now sufficiently large so that they provide similar quality audits to those provided by the Big 4 audit firms.

Francis and Yu (2009) and Choi et al. (2010) examine the effect of Big 4 auditor office size on audit quality. These authors suggest that the same economic mechanisms that drive higher quality audit work for larger audit firms (Big4 audit firms) drive auditors from larger offices (based on number of employees per office) to be more independent. Both studies find that auditors who operate from larger offices constrain their audit clients to report more conservatively. This conclusion is supported by findings of clients having reduced discretionary accruals, reduced probabilities of barely meeting or beating important earnings benchmarks, and increased probabilities of receiving a going concern modified audit opinion when their auditors operate from larger offices.

Prior research suggests that going concern modifications may be used to protect the auditor from litigation costs (Carcello and Palmrose, 1994). Another study builds upon those results and finds that the probability of a going concern modification is negatively related to audit quality (Buslepp and Victoravich, 2011). Thus, it's questionable whether the going concern modification evidence presented in Francis and Yu (2009) supports a conclusion of a positive relation between auditor office size and audit quality. Other researchers suggest that high quality auditors are those that improve the quality of the audited information (Watkins, Hillison \& Morecroft, 2004; Wallace, 1980; Titman and Trueman, 1986; and Davidson and Neu, 1993).

Prior research suggests that earnings management can be used for opportunistic reasons. Specifically, these studies find that managers opportunistically manipulate earnings to improve their bonuses (Healy, 1985), look bad to government officials during federal investigations (Jones, 1991), to meet or beat important earnings benchmarks (Burgstahler and Dichev, 1997), and to improve debt ratios (Defond and Jiambalvo, 1994). However, there are also studies that find evidence of earnings management being used to communicate management's private information to the public (Subramanyam, 1996; Guay et al., 1996; and Louis and Robinson, 2005). Therefore, it's unclear whether greater conservatism in earnings leads to better earnings quality.

Relatively few studies examine the impact of high quality auditors on earnings informativeness (Krishnan, 2003 and Mascarenhas, Cahan \& Naiker, 2010). These studies build on prior research that finds greater earnings conservatism for clients of larger auditors and industry expert auditors (Becker et al., 1998 and Balsam, Krishnan \& Yang, 2003). Krishnan (2003) and Mascarenhas et al. (2010) find that discretionary accruals for clients of industry expert auditors are no more highly associated with future returns than those for clients of non industry expert auditors, but the discretionary accruals of clients of larger audit firms are more highly associated with future returns than for clients of smaller audit firms. These results suggest that while larger audit firms improve the earnings quality of their clients, industry expert auditors may not.

Prior research finds that auditors from larger offices constrain managers of client firms to report more conservatively (Francis and $\mathrm{Yu}, 2009$ and Choi et al., 2010) and suggest that auditors from larger offices have more reputation to lose from audit failure than their smaller office counterparts do. Incentives drive auditors from larger offices towards greater levels of independence with the expected result of greater auditor constraint over aggressive reporting (lower discretionary accruals) by the aggressive clients.

Alternatively, auditors from larger offices may be unable to differentiate between the two types of earnings management. Thus, auditors from larger offices may indiscriminately constrain the earnings management behavior of all clients resulting in earnings quality which may be lower for clients of auditors from larger offices. 
Greater auditor incentives to avoid reputation damage results in greater independence, which ultimately results in greater audit quality for all clients (DeAngelo, 1981). One reason that auditors may not have similar abilities is that heightened incentives to avoid reputation damage may result in the auditor's excessive concerns about aggressive reporting. These excessive concerns may cloud the auditor's judgment, making her unable to separate opportunistic from informative earnings management. As Francis and Yu (2009) and Choi et al. (2010) suggest, incentives to protect auditor reputation are likely stronger for auditors from larger offices.

Auditors from larger offices generally have access to additional office level resources. Greater demands on the auditor's resources may yield less audit resources per engagement and may harm the auditor's ability to service their client (Hansen, Kumar \& Sullivan, 2008).

Excessive conservatism may filter out management's informative earnings management, which could harm the earnings signal. Earnings quality may decrease according to the size of the auditor's office. The effects of auditor office size on the quality of earnings are an unsettled empirical question.

Since auditors have no direct impact on earnings quality, their impact on earnings occurs through management's discretion over earnings. Therefore, the components of earnings that most exhibit management's discretion are also the components most affected by the auditor. Management has little discretion over the reporting of cash flows. The focus of this research is to examine the auditor's influence on earnings by investigating the quality of the accruals component of earnings. Prior literature suggests there is a normal (nondiscretionary) component and an abnormal (discretionary) component of accruals (Mascarenhas et al., 2010), and management has more discretion over the abnormal (discretionary) component. Consequently, the abnormal (discretionary) accruals component of earnings is the area most expected to exhibit the auditor's impact on the quality of earnings. On the other hand, there is the possibility that the auditor's influence may be present in the normal (nondiscretionary) accruals component of earnings. The examination of the quality of the normal (nondiscretionary) accruals of clients audited by auditors from larger versus smaller offices is also included in this analysis.

\section{Data and Methodology}

FASB Concept Statement 1 suggests that high quality earnings should have predictive value (FASB SFAC 1). Therefore, the differential quality of the components of earnings are examined for each component's predictive value. Two alternative measures of the predictive value of earnings are tested.

Concept Statement 1 suggests that earnings contain a predictive value about future cash flows. Several studies have tested the predictive value of components of current earnings for future cash flows (Subramanyam, 1996 and Doyle, Lundholm \& Soliman, 2003), and some authors have tested for differences in this form of predictive value across clients of different auditor types (Krishnan, 2003).

The predictive value of cash flows is an especially appropriate measure of earnings quality. Doyle et al. (2003) suggests this metric because cash flows are not influenced by opportunistic earnings management. If accruals are used to communicate management's private information, then future cash flows should be positively related to current accruals. If management's private information is filtered from accruals by an overly conservative auditor, then the association between current accruals and future cash flows may be reduced. For these reasons, the association between current period's accruals and future cash flows from operations are examined.

It is known that the natural variation in the cash flows realization process makes cash flow a relatively poor measure of performance. Accruals, however, are designed to cause earnings to converge towards true economic performance. This convergence allows accrual based earnings to better predict future cash flows than the same period's cash flows. The ability of current earnings to predict future earnings is important as noted by Subramanyam (1996) and Krishnan (2003). Both use the association between current period components of earnings and future profitability as a proxy for the predictive value of current period earnings. A second measure of the predictive value of discretionary accruals is the association between current discretionary accruals and future profitability. 
Table 1. Sample Selection Criteria

\begin{tabular}{ll}
\hline Selection Criteria & Observations \\
\hline $\begin{array}{l}\text { All Firm years serviced by Big4 Auditors listed on Audit Analytics and Compustat } \\
\text { between 2003-2008, with necessary data available. }\end{array}$ & 16,428 \\
$\begin{array}{ll}\text { Less: Financial Institutions (SIC } 6000-6999) \text { and Utilities (SIC } 4900-4999) \\
\text { Less: Observations with missing values }\end{array}$ & $(2,387)$ \\
Full sample observations & 6,493 \\
\hline
\end{tabular}

Table 1 presents the sample reconciliation.

Table 1 presents the sample reconciliation, which includes all firm-years with the necessary data available to compute test variables. Because prior literature suggests that earnings audited by larger audit firms are of higher quality than earnings audited by smaller audit firms, audit firm size may affect the results. To eliminate this potential problem, the sample focuses on just one, relatively large, homogenously sized auditor group. The sample consists of clients audited by the Big4 audit firms. Firm-year observations include those with fiscal years between 2003 and $2008(16,428)$. The sample period begins at 2003 to avoid problems presented by pooling observations from the pre-SOX and post-SOX time periods. The sample period ends at 2008 because the analyses required up to three years of future cash flows. To compute these variables, data are taken for each firm year in Audit Analytics and Compustat. Firms are eliminated if they operate primarily in the financial (SICs between 6000-6999) industry or utility (SICs between 4900-4999) industry because of the different reporting requirements in these industries (2,387). Firm-years without the necessary data to compute the variables are also eliminated $(7,548)$. The remaining firm-years comprise the sample $(6,493)$.

Auditor office size, OFFICESIZE, is measured as the natural log of total audit fees earned by the auditor's office and the natural $\log$ of clients serviced by the office. A proxy for the discretionary accruals component of earnings is used; the cross sectional performance adjusted Jones model (Kothari, Leone \& Wasley, 2005) was chosen. This model regresses total accruals on the inverse of lagged total assets, current period change in sales, current period gross PPE, and current period income before extraordinary items and discontinued operations. Each element is scaled by lagged total assets. This model is estimated by fiscal year within each industry (2 digit SIC code). The nondiscretionary component of total accruals is the predicted value from the regression. Thus, the discretionary component of total accruals is the residual. This approach is defined below in equation 1 whereby the analyses is limited to industry-fiscal years that contain at least 6 observations.

$$
\operatorname{ACCRUALS}_{j t}=\alpha_{0}+\alpha_{1}\left(1 / \mathrm{LAGASSET}_{j t}\right)+\alpha_{2} \mathrm{PPE}_{j t}+\alpha_{3} \mathrm{CHGSALE}_{j t}+\alpha_{4} \mathrm{ROA}_{j t}+e_{j t}
$$

Where:

ACCRUALS $S_{j t}$ is income before extraordinary activities minus cash flow from operating activities scaled by $t-1$ total assets for firm $j$ in year $t$

$L_{A A S S E T}$ it is the total assets for firm $j$ at the beginning of fiscal year $t$.

$P P E_{j t}$ is the level of gross property, plant, and equipment for firm $j$ at the end of fiscal year $t$ scaled by LAGASSET $T_{j t}$.

$C_{C H S A L E}$ is the current period change in revenue scaled by LAGSSET $T_{j t}$.

$R O A_{j t}$ is the current period's income before extraordinary items scaled by LAGASSET $T_{j \text {. }}$

$e_{j t}$ is firm j's residual from the cross sectional regression at fiscal year $t$. This is the discretionary accrual, $D A_{j t}$.

Testing the differential association between future cash flows and current discretionary accruals is similar to that in Subramanyam (1996) and Krishnan (2003). In order to control for the predictive value of each of the components of current earnings, these studies included each of the components in the regressions.

Determining which period the predicted future cash flows will occur presents its own difficulties. Altamuro et al. (2005) addressed this issue by regressing the accumulations of multiple future period cash flows from operations on current period earnings. This approach avoids an assumption regarding which future period's cash flow is relevant for the current period's earnings to predict. Accumulations of 1, 2 and 3 year ahead cash flows from operations 
values, FUTCF, are regressed on the components of earnings and their interactions with OFFICESIZE. Office size impact on the predictive value of each accruals component are investigated. Coefficients on the interactions between OFFICESIZE and each component of accruals provide evidence of this impact. A positive (negative) coefficient on these interactions suggest that auditors from larger offices properly (improperly) filter the accruals components of the opportunistic earnings management. Further, consistent with Doyle et al. (2003), growth in sales (GROWTH) is controlled for. Heteroskedasticity is also controlled for by including (not shown) fiscal year fixed effects dummies. The model is shown below:

$$
\begin{aligned}
& \text { FUTCF }_{j t+1-3}=¥_{0}+\Psi_{1} \text { OANCF }_{j t}+¥_{2} N D A_{j t}+\Psi_{3} \text { DA }_{j t}+¥_{4} \text { OFFICESIZE }_{j t}+¥_{5} \text { OFFICESIZE }_{j t} * \text { OANCF }_{j t}+
\end{aligned}
$$

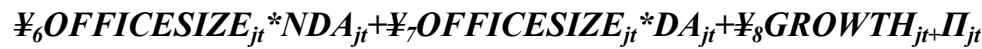

Where:

FUTCF $_{j t+1-3}$ is firm j's annual Cash Flows from Operations accumulated over fiscal years $t+1$ to $t+3$, scaled by total assets at the end of fiscal year $t+1$.

$O A N C F_{j t}$ is firm j's annual Cash Flows from Operations over fiscal year t, scaled by lagged total assets.

$N D A_{j t}$ is firm j's nondiscretionary accruals, scaled by lagged total assets, over fiscal year $t$.

$D A_{j t}$ is firm j's discretionary accruals, scaled by lagged total assets, over fiscal year $t$.

OFFICESIZE $_{j t}$ is firm j's auditor's office size for fiscal year $t$. This is either the natural log of the office's client count or the natural log of the office's fees earned.

GROWTH ${ }_{j t}$ is firm j's percentage growth in sales over fiscal year $t$.

$¥$ 's are coefficients to be estimated

$\Pi_{j t}$ is the random error term for firm $j$ over fiscal year $t$.

Consistent with Altamuro, Beatty and Weber (2005), future income values (FUTNI) are accumulated over the 1, 2 and 3 years into the future. Similar to the tests of the predictive value for future cash flows, future earnings are regressed on each component of current earnings and it's interaction with OFFICESIZE. Because extraordinary items and discontinued operations are, by their nature, unusual, the predictable portion of earnings is that which is computed before these items. Therefore, the measure of future profitability, FUTNI, is the accumulation of 1, 2, or 3 years of income before extraordinary items and discontinued operations. Similar to that in equation 2, the coefficients on the interactions between OFFICESIZE and each component of accruals provide evidence of the impact of OFFICESIZE on the predictive value of each component of accruals. A positive (negative) coefficient on these interactions would suggest that auditors from larger offices properly (improperly) filter the accruals components of the opportunistic earnings management. Growth in sales, GROWTH, is controlled for because sales growth also impacts future income levels. The regression model used to test this association is given as equation 3 below:

$$
\begin{array}{r}
\text { FUTNI }_{j t+1-3}=\Omega_{0}+\Omega_{1} \text { OANCF }_{j t}+\Omega_{2} \text { NDA }_{j t}+\Omega_{3} \text { DA }_{j t}+\Omega_{4} \text { OFFICESIZE }_{j t}+\Omega_{5} \text { OFFICESIZE }_{j t} * \text { CFO }_{j t}+ \\
\Omega_{6} \text { OFFICESIZE }_{j t} * N D A_{j t}+\Omega_{7} \text { OFFICESIZE }_{j t} * \operatorname{DA}_{j t}+\Omega_{8} \text { GROWTH }_{j t}+E_{j t}
\end{array}
$$

Where:

FUTNI $_{j t+1-3}$ is firm j's annual Income Before Extraordinary Items and Discontinued Operations, per share, accumulated over fiscal years $t+1$ to $t+3$.

$O_{A N C F}{ }_{j t}$ is firm j's annual Cash Flows from Operations, scaled by lagged total assets, over fiscal year $t$.

$N D A_{j t}$ is firm $j$ 's nondiscretionary accruals, scaled by lagged total assets, over fiscal year $t$.

$D A_{j t}$ is firm $j$ 's discretionary accruals, scaled by lagged total assets, over fiscal year $t$.

OFFICESIZE $_{j t}$ is firm j's auditor's office size for fiscal year $t$. This is either the natural log of the office's client count or the natural log of the office's fees earned.

GROWTH ${ }_{j t}$ is firm j's percentage growth in sales over fiscal year $t$.

$\Omega$ 's are coefficients to be estimated

$E_{j t}$ is the random error term for firm $j$ over fiscal year $t$. 


\section{Results}

Table 2 presents the descriptive statistics, and Table 3 presents the correlation matrix for the sample. Note that all variables have been winsorized at the top and bottom $1 \%$ levels. The correlation matrix presents bivariate correlations for all of the independent variables in the sample. OFFICESIZE1 and OFFICESIZE2 are highly positively correlated. The other bivariate correlations are generally as expected. One exception is the positive correlation between DA and OFFICESIZE1. Although this is inconsistent with expectations, this likely differs in a multivariate context.

Table 2. Descriptive Statistics

\begin{tabular}{llllll}
\hline & Mean & Median & Std Dev & Minimum & Maximum \\
\hline FUTCF3 & 0.207 & 0.280 & 0.520 & -2.430 & 1.219 \\
FUTCF2 & 0.120 & 0.178 & 0.342 & -1.643 & 0.726 \\
FUTCF1 & 0.051 & 0.083 & 0.181 & -0.929 & 0.326 \\
FUTNI3 & -0.004 & 0.132 & 0.599 & -3.196 & 0.972 \\
FUTNI2 & -0.011 & 0.086 & 0.391 & -1.992 & 0.578 \\
FUTNI1 & -0.013 & 0.042 & 0.212 & -1.167 & 0.257 \\
OANCF & 0.066 & 0.091 & 0.195 & -0.869 & 0.500 \\
DA & -0.084 & -0.031 & 0.480 & -2.305 & 1.594 \\
NDA & 0.008 & -0.032 & 0.494 & -1.886 & 2.195 \\
OFFICESIZE1 & 3.499 & 3.584 & 1.372 & 0.000 & 6.781 \\
OFFICESIZE2 & 17.100 & 17.326 & 1.442 & 9.731 & 20.309 \\
GROWTH & 17.903 & 10.965 & 41.757 & -72.504 & 275.210 \\
\hline
\end{tabular}

Table 2 presents the descriptive statistics for the variables in our sample. These descriptive statistics include the mean, median, standard deviation, minimum, and maximum values. The variables used are defined below.

Variable Definitions:

$F U T C F 3=$ future cash flows from operations for fiscal years $t+1$ to $t+3$ scaled by $t+1$ total assets

$F U T C F 2=$ future cash flows from operations for fiscal years $t+1$ to $t+2$ scaled by $t+1$ total assets

$F U T C F 1=$ future cash flows from operations for fiscal years $t+1$ scaled by $t+1$ total assets

FUTNI3 = sum of annual income before extraordinary items for years $t+1$ to $t+3$ scaled by $t+1$ total assets

FUTN2 $=$ sum of annual income before extraordinary items for years $t+1$ to $t+2$ scaled by $t+1$ total assets

FUTNI1 = sum of annual income before extraordinary items for years $t+1$ scaled by $t+1$ total assets

$O A N C F=$ operating activities minus net cash flow all scaled by $t-1$ total assets

$D A=$ discretionary accruals; the residual derived from the following model:

ACCRUALS $_{j t}=\alpha_{0}+\alpha_{1}\left(1 /\right.$ LAGASSET $\left._{j t}\right)+\alpha_{2} P P E_{j t}+\alpha_{3}$ SALEREC $_{j t}+\alpha_{4} R O A_{j t}+e_{j t}$, where

$A C C R U A L S_{j t}=$ income before extraordinary activities minus cash flow from operating activities scaled by $t-1$ total assets for firm $j$ in year $t$

$L A G A S S E T_{j t}=t-1$ assets for firm $j$ in year $t$

$P P E_{j t}=$ gross property, plant and equipment scaled by $t-1$ assets for firm $j$ in year $t$

$C H G S A L E_{j t}=$ year-over-year change in revenue scaled by $t-1$ assets for firm $j$ in year $t$

$R O A_{j t}=$ return on assets for firm $j$ in year $t$ scaled by $t-1$ total assets

$N D A=$ non-discretionary accruals; $A C C R U A L S-D A$

OFFICESIZE 1 = natural log of the auditor office client count

OFFICESIZE2 $=$ natural $\log$ of the auditor office fees earned

GROWTH = year over year percentage growth in sales 
Table 3. Correlation Matrix

\begin{tabular}{lllllll}
\hline & OANCF & DA & NDA & OFFICESIZE1 & OFFICESIZE2 & GROWTH \\
\hline OANCF & 1 & & & & & \\
DA & -0.2886 & 1 & & & & \\
NDA & 0.2887 & -0.9423 & 1 & & & \\
OFFICESIZE1 & -0.0876 & 0.0254 & -0.0292 & 1 & & \\
OFFICESIZE2 & 0.0061 & -0.0037 & 0.0075 & 0.8009 & 1 & \\
GROWTH & -0.0034 & -0.0173 & -0.0036 & -0.0003 & -0.0174 & 1 \\
\hline
\end{tabular}

Table 3 presents the bivariate correlations between each of our sample variables. The variables are as defined in Table 2.

Table 4 presents the results of regressing future cash flows on current earnings components. The table is divided into 3 columns relating to the different dependent variables $(1,2$, and 3 periods of accumulated future cash flows from operations). Each column is then further subdivided into two separate results columns, each of which presents the results when using one measure of OFFICESIZE or the other. The results include coefficient estimates, p-values (in parentheses underneath the respective coefficient estimate), and significance levels (in asterisks). Each regression includes (not shown, for brevity) fiscal year fixed effects indicators.

Table 4. Regression Results for Future Cash Flows

\begin{tabular}{|c|c|c|c|c|c|c|}
\hline 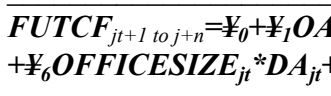 & $\begin{array}{l}\mathrm{VCF}_{j t}+\Psi_{2} D \\
{ }_{7} \mathrm{OFFICE}\end{array}$ & $\begin{array}{l}{ }_{N D A_{j t}}+\Psi_{4} O \\
N D A_{j t}+\Psi_{8}\end{array}$ & $\begin{array}{l}S I Z E_{j t}+\Psi_{5} \\
T H_{j t}+\pi_{j t}\end{array}$ & $\operatorname{CESIZE}_{j t} * \mathrm{O}$ & & \\
\hline & FUTCF3 & & FUTCF2 & & FUTCF1 & \\
\hline OANCF & $\begin{array}{l}2.014 * * * \\
(0.0000)\end{array}$ & $\begin{array}{l}2.520 * * * \\
(0.0000)\end{array}$ & $\begin{array}{l}1.346^{* * *} \\
(0.0000)\end{array}$ & $\begin{array}{l}1.565^{* * * *} \\
(0.0000)\end{array}$ & $\begin{array}{l}0.702 * * * \\
(0.0000)\end{array}$ & $\begin{array}{l}0.733 * * * \\
(0.0000)\end{array}$ \\
\hline DA & $\begin{array}{l}0.373 * * * \\
(0.0000)\end{array}$ & $\begin{array}{l}-0.081 \\
(0.7595)\end{array}$ & $\begin{array}{l}0.224 * * * \\
(0.0001)\end{array}$ & $\begin{array}{l}-0.124 \\
(0.4646)\end{array}$ & $\begin{array}{l}0.120 * * * \\
(0.0001)\end{array}$ & $\begin{array}{l}-0.054 \\
(0.5523)\end{array}$ \\
\hline NDA & $\begin{array}{l}0.390 * * * \\
(0.0000)\end{array}$ & $\begin{array}{l}-0.085 \\
(0.7491)\end{array}$ & $\begin{array}{l}0.227 * * * \\
(0.0001)\end{array}$ & $\begin{array}{l}-0.119 \\
(0.4812)\end{array}$ & $\begin{array}{l}0.119 * * * \\
(0.0001)\end{array}$ & $\begin{array}{l}-0.042 \\
(0.6425)\end{array}$ \\
\hline OFFICESIZE1 & $\begin{array}{l}-0.006 \\
(0.1055)\end{array}$ & & $\begin{array}{l}-0.003 \\
(0.1847)\end{array}$ & & $\begin{array}{l}-0.002 \\
(0.1999)\end{array}$ & \\
\hline OFFICESIZE 1 *OANCF & $\begin{array}{l}-0.000 \\
(0.9631)\end{array}$ & & $\begin{array}{l}0.000 \\
(0.6902)\end{array}$ & & $\begin{array}{l}0.000 \\
(0.4900)\end{array}$ & \\
\hline OFFICESIZE $1 *$ DA & $\begin{array}{l}-0.015 \\
(0.5220)\end{array}$ & & $\begin{array}{l}0.000 \\
(0.9837)\end{array}$ & & $\begin{array}{l}-0.002 \\
(0.8024)\end{array}$ & \\
\hline OFFICESIZE $1 *$ NDA & $\begin{array}{l}-0.023 \\
(0.3403)\end{array}$ & & $\begin{array}{l}-0.003 \\
(0.8433)\end{array}$ & & $\begin{array}{l}-0.002 \\
(0.7780)\end{array}$ & \\
\hline GROWTH & $\begin{array}{l}-0.000 \\
(0.4199)\end{array}$ & $\begin{array}{l}-0.000 \\
(0.4748)\end{array}$ & $\begin{array}{l}-0.000 * * \\
(0.0256)\end{array}$ & $\begin{array}{l}-0.000 * * \\
(0.0332)\end{array}$ & $\begin{array}{l}-0.000 * * \\
(0.0192)\end{array}$ & $\begin{array}{l}-0.000^{* *} \\
(0.0248)\end{array}$ \\
\hline OFFICESIZE2 & & $\begin{array}{l}0.002 \\
(0.5907)\end{array}$ & & $\begin{array}{l}0.002 \\
(0.4054)\end{array}$ & & $\begin{array}{l}0.001 \\
(0.4556)\end{array}$ \\
\hline OFFICESIZE2*OANCF & & $\begin{array}{l}-0.030 * \\
(0.0729)\end{array}$ & & $\begin{array}{l}-0.013 \\
(0.2294)\end{array}$ & & $\begin{array}{l}-0.002 \\
(0.7545)\end{array}$ \\
\hline OFFICESIZE2*DA & & $\begin{array}{l}0.023 \\
(0.1321)\end{array}$ & & $\begin{array}{l}0.020 * * \\
(0.0395)\end{array}$ & & $\begin{array}{l}0.010 * \\
(0.0677)\end{array}$ \\
\hline
\end{tabular}




\begin{tabular}{l|ll|ll|ll} 
OFFICESIZE2*NDA & & 0.023 & & $0.020^{* *}$ & & $0.009^{*}$ \\
& & $(0.1354)$ & & $(0.0466)$ & & $(0.0927)$ \\
CONSTANT & & & & & \\
& $0.131^{* * *}$ & 0.083 & $0.083^{* * *}$ & 0.043 & $0.024^{* * *}$ & 0.004 \\
Obs. & $(0.0000)$ & $(0.1721)$ & $(0.0000)$ & $(0.2683)$ & $(0.0041)$ & $(0.8512)$ \\
& 6493 & 6493 & 6493 & 6493 & 6493 & 6493 \\
Adj. $\mathrm{R}^{2}$ & 0.5829 & 0.5830 & 0.6048 & 0.6050 & 0.5897 & 0.5898
\end{tabular}

Table 4 presents the results of regression of future cash flows from operations, accumulated over 1, 2, or 3 fiscal years into the future, on current period earnings components, OFFICESIZE, and interactions between each of the earnings components and OFFICESIZE. Table 4 presents the results by dependent variable (1,2, or 3 annual future cash flows from operations). Within each dependent variable category the results are also separated by which OFFICESIZE variable was used (OFFICESIZE1 or OFFICESIZE2). Variables are as defined in Table 2.

$* * *, * *, *$ denote significance at the $0.01,0.05$, and 0.10 levels, respectively. P-values are represented in parentheses.

Focusing on the OFFICESIZE1 results, the coefficients on OANCF are all significantly positive, and rather large. This suggests that current period cash flows have strong predictive value for future cash flows. Coefficient estimates on both DA and NDA are significantly positive in each regression. These results suggest that DA and NDA have predictive value for future cash flows. The coefficients on the interaction between each of DA and OFFICESIZE1 and NDA and OFFICESIZE1 are insignificant.

The results of the regressions using OFFICESIZE2 present another picture. Again, the coefficients on OANCF are consistently positive and relatively large. However, the coefficients on DA and NDA are insignificant across each of the specifications. Additionally, the coefficients on the interactions between DA and OFFICESIZE2 and NDA and OFFICESIZE2 are significantly positive when using either FUTCF1 or FUTCF2 as the dependent variable. This suggests that both DA and NDA have greater levels of predictive value for cash flows from operations occurring within the next 2 years for clients of auditors from larger offices than for clients of auditors from smaller offices.

In Table 5, results of regressing future income values on current period earnings components are presented and show significantly positive coefficients for OANCF. This suggests that current period operating cash flows have strong predictive value for future income levels. Further, across all specifications, there are significantly positive coefficients on each NDA variable and on all but one DA variable across the future income regressions. Therefore, both NDA and DA can have predictive value for future earnings. The coefficients on each of the accruals interactions (DA or NDA multiplied by either OFFICESIZE variable), across all 6 regression specifications, were all insignificant. Thus, using a Big 4 auditor from a larger office doesn't necessarily cause an improvement in the predictive value of earnings.

It is possible that either the mixed results found in the interaction variables in the future cash flow analyses or the lack of results found in the interaction variables in the future net income analyses may be caused by a nonlinear relation between the predictive value of current earnings components and OFFICESIZE. Such a nonlinear relation would not be identifiable with this type of regression. But a relationship can be identified using subsample regressions partitioned by OFFICESIZE quintile portfolios as noted in Tables 6 and 7 .

Tables 6 and 7 present the results of portfolio regressions of future cash flows and future earnings on current period earnings components, where portfolios are assembled based on the observation's quintile of OFFICESIZE. Each panel presents the results partitioned by the dependent variable $(1,2$, or 3 of future annual cash flows from operations or income values) which is further partitioned by quintile of OFFICESIZE. These results include coefficient estimates, their respective p-values (in parentheses below the coefficient estimate), and the significance level (in asterisks).

Panel A of Table 6 presents the results of portfolio regressions of future cash flows from operations on current period earnings components when OFFICESIZE1 is used to determine the portfolios. The coefficient estimates on OANCF are again significantly positive across each of the quintiles of OFFICESIZE and across each of the dependent variable specifications. The coefficients appear relatively similar across the quintiles of OFFICESIZE1, and this appears to be the case for each of the dependent variable specifications. Additionally, each of the coefficient estimates on both NDA and DA is significantly positive. This suggests that current period accruals, both discretionary and nondiscretionary, have predictive value for future earnings. Moreover, rather than increasing OFFICESIZE1, as expected, the coefficients on both DA and NDA appear to decrease across the first four quintiles 
of OFFICESIZE1 and then slightly increase in the fifth quintile of OFFICESIZE1. Although not shown here, the informativeness of DA and NDA for future cash flows generally appears to exhibit a slight U-shape in OFFICESIZE.

The general decrease in the informativeness of accruals across the first 4 quintiles of OFFICESIZE1 is consistent with an auditor whose concern about reputation loss and capacity stress, and therefore his inability to differentiate between opportunistic and informative accruals, is increasing. However, the slight increase in the informativeness of accruals for firms with auditors from the largest offices is consistent with auditors from very large offices having access to greater levels of local audit expertise. This greater local area expertise is likely aiding in the auditor's ability to separate the types of accruals. It's possible that the greater local expertise cannot affect the audit until there is a sufficiently high amount. This may only happen when the offices are extremely large ( $5^{\text {th }}$ quintile).

Table 5. Regression Results for Future Net Income

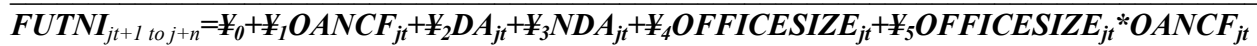



\begin{tabular}{|c|c|c|c|c|c|c|}
\hline & FUTNI3 & & FUTNI2 & & FUTNI1 & \\
\hline OANCF & $\begin{array}{l}2.204 * * * \\
(0.0000)\end{array}$ & $\begin{array}{l}2.305 * * * \\
(0.0000)\end{array}$ & $\begin{array}{l}1.467 * * * \\
(0.0000)\end{array}$ & $\begin{array}{l}1.425^{* * *} * \\
(0.0000)\end{array}$ & $\begin{array}{l}0.773 * * * \\
(0.0000)\end{array}$ & $\begin{array}{l}0.668^{* * *} * \\
(0.0000)\end{array}$ \\
\hline DA & $\begin{array}{l}0.649 * * * \\
(0.0000)\end{array}$ & $\begin{array}{l}0.764 * * \\
(0.0159)\end{array}$ & $\begin{array}{l}0.426^{* * *} \\
(0.0000)\end{array}$ & $\begin{array}{l}0.489 * * \\
(0.0160)\end{array}$ & $\begin{array}{l}0.211 * * * \\
(0.0000)\end{array}$ & $\begin{array}{l}0.176 \\
(0.1190)\end{array}$ \\
\hline NDA & $\begin{array}{l}0.685^{* * *} \\
(0.0000)\end{array}$ & $\begin{array}{l}0.806 * * \\
(0.0107)\end{array}$ & $\begin{array}{l}0.443 * * * \\
(0.0000)\end{array}$ & $\begin{array}{l}0.520 * * \\
(0.0101)\end{array}$ & $\begin{array}{l}0.218 * * * \\
(0.0000)\end{array}$ & $\begin{array}{l}0.229 * * \\
(0.0425)\end{array}$ \\
\hline OFFICESIZE1 & $\begin{array}{l}-0.005 \\
(0.2358)\end{array}$ & & $\begin{array}{l}-0.004 \\
(0.1573)\end{array}$ & & $\begin{array}{l}-0.002 \\
(0.1526)\end{array}$ & \\
\hline OFFICESIZE $1 *$ OANCF & $\begin{array}{l}0.000 \\
(0.2444)\end{array}$ & & $\begin{array}{l}0.000 * * \\
(0.0408)\end{array}$ & & $\begin{array}{l}0.000 * * * \\
(0.0046)\end{array}$ & \\
\hline OFFICESIZE $1 *$ DA & $\begin{array}{l}-0.017 \\
(0.5560)\end{array}$ & & $\begin{array}{l}-0.010 \\
(0.5841)\end{array}$ & & $\begin{array}{l}-0.000 \\
(0.9982)\end{array}$ & \\
\hline OFFICESIZE $1 *$ NDA & $\begin{array}{l}-0.026 \\
(0.3637)\end{array}$ & & $\begin{array}{l}-0.015 \\
(0.4024)\end{array}$ & & $\begin{array}{l}-0.002 \\
(0.8539)\end{array}$ & \\
\hline GROWTH & $\begin{array}{l}-0.001 * * * \\
(0.0000)\end{array}$ & $\begin{array}{l}-0.001 * * * \\
(0.0000)\end{array}$ & $\begin{array}{l}-0.000^{* * *} \\
(0.0000)\end{array}$ & $\begin{array}{l}-0.000 * * * \\
(0.0000)\end{array}$ & $\begin{array}{l}-0.000 * * \\
(0.0102)\end{array}$ & $\begin{array}{l}-0.000 * * \\
(0.0124)\end{array}$ \\
\hline OFFICESIZE2 & & $\begin{array}{l}0.000 \\
(0.9460)\end{array}$ & & $\begin{array}{l}-0.000 \\
(0.9251)\end{array}$ & & $\begin{array}{l}-0.001 \\
(0.6735)\end{array}$ \\
\hline OFFICESIZE2*OANCF & & $\begin{array}{l}-0.006 \\
(0.7687)\end{array}$ & & $\begin{array}{l}0.003 \\
(0.8352)\end{array}$ & & $\begin{array}{l}0.006 \\
(0.3687)\end{array}$ \\
\hline OFFICESIZE2*DA & & $\begin{array}{l}-0.010 \\
(0.5724)\end{array}$ & & $\begin{array}{l}-0.006 \\
(0.6218)\end{array}$ & & $\begin{array}{l}0.002 \\
(0.7620)\end{array}$ \\
\hline OFFICESIZE $2 *$ NDA & & $\begin{array}{l}-0.012 \\
(0.4979)\end{array}$ & & $\begin{array}{l}-0.008 \\
(0.5159)\end{array}$ & & $\begin{array}{l}-0.001 \\
(0.8833)\end{array}$ \\
\hline CONSTANT & $\begin{array}{l}-0.138 * * * \\
(0.0000)\end{array}$ & $\begin{array}{l}-0.160 * * \\
(0.0278)\end{array}$ & $\begin{array}{l}-0.130^{* * *} \\
(0.0000)\end{array}$ & $\begin{array}{l}-0.139 * * * \\
(0.0027)\end{array}$ & $\begin{array}{l}-0.094 * * * \\
(0.0000)\end{array}$ & $\begin{array}{l}-0.092 * * * \\
(0.0004)\end{array}$ \\
\hline Obs. & 6493 & 6493 & 6493 & 6493 & 6493 & 6493 \\
\hline Adj. $R^{2}$ & 0.5516 & 0.5513 & 0.5709 & 0.5705 & 0.5465 & 0.5458 \\
\hline
\end{tabular}


Table 5 presents the results of regressions of future income values, accumulated over 1,2, or 3 fiscal years into the future, on current period earnings components, OFFICESIZE, and interactions between each of the earnings components and OFFICESIZE.

Table 5 presents the results by dependent variable (1, 2, or 3 annual future income values). Within each dependent variable category the results are also separated by which OFFICESIZE variable was used (OFFICESIZE1 or OFFICESIZE2). Variables are as defined in Table 2.

$* * *, * *, *$ denote significance at the $0.01,0.05$, and 0.10 levels, respectively. P-values are represented in parentheses.

Table 6. Partitioned Regressions for Future Cash Flows

$$
\text { FUTCF }_{j t+l \text { to } j+n}=\Psi_{0}+\Psi_{1} \mathrm{OANCF}_{j t}+\Psi_{2} \mathrm{DA}_{j t}+\Psi_{3} \mathrm{ND} A_{j t}+\Psi_{4} \mathrm{OFFICESIZE}_{j t}+\Psi_{8} \mathrm{GROWTH}_{j t}+\Pi_{j t}
$$

\begin{tabular}{|c|c|c|c|c|c|c|c|c|c|c|c|c|c|c|c|}
\hline \multicolumn{16}{|c|}{ Panel A: Quintile Regressions by Officesize1 } \\
\hline & \multicolumn{5}{|c|}{ FUTCF3 } & \multicolumn{5}{|c|}{ FUTCF2 } & \multicolumn{5}{|c|}{ FUTCF1 } \\
\hline & OANCF & DA & NDA & $\begin{array}{c}\text { PERC } \\
\text { GROWTH }\end{array}$ & CONSTANT & OANCF & DA & NDA & $\begin{array}{c}\text { PERC } \\
\text { GROWTH }\end{array}$ & CONSTANT & OANCF & DA & NDA & $\begin{array}{c}\text { PERC } \\
\text { GROWTH }\end{array}$ & CONSTANT \\
\hline \multirow[t]{2}{*}{ Q1 } & $1.947^{* * * *}$ & $0.516^{* * *}$ & $0.532^{* * *}$ & $-0.000^{*}$ & $0.171^{* * *}$ & $1.300^{* * *}$ & $0.313^{* * * *}$ & $0.313^{* * *}$ & $-0.000^{* * *}$ & $0.111^{* * *}$ & $0.672^{* * * *}$ & $0.162^{* * *}$ & $0.167^{* * *}$ & -0.000 ** & $0.028^{* *}$ \\
\hline & $(0.0000)$ & $(0.0000)$ & $(0.0000)$ & $(0.0509)$ & $(0.0000)$ & $(0.0000)$ & $(0.0000)$ & $(0.0000)$ & $(0.0015)$ & $(0.0000)$ & $(0.0000)$ & $(0.0000)$ & $(0.0000)$ & $(0.0125)$ & $(0.0198)$ \\
\hline \multirow[t]{2}{*}{ Q2 } & $2.170^{* * *}$ & $0.353^{* * *}$ & $0.358^{* * *}$ & -0.000 & $0.100^{* *}$ & $1.423^{* * *}$ & $0.222 * * *$ & $0.239^{* * *}$ & -0.000 & $0.065^{* *}$ & $0.730^{* * *}$ & $0.127^{* * *}$ & $0.133^{* * *}$ & 0.000 & 0.024 \\
\hline & $(0.0000)$ & $(0.0000)$ & $(0.0000)$ & $(0.6187)$ & $(0.0255)$ & $(0.0000)$ & $(0.0000)$ & $(0.0000)$ & $(0.8291)$ & $(0.0278)$ & $(0.0000)$ & $(0.0000)$ & $(0.0000)$ & $(0.5696)$ & $(0.1369)$ \\
\hline \multirow[t]{2}{*}{ Q3 } & $2.087^{* * *}$ & $0.347^{* * *}$ & $0.306^{* * *}$ & 0.000 & 0.068 & $1.378^{* * *}$ & $0.257^{* * *}$ & $0.232^{* * * *}$ & 0.000 & $0.047^{*}$ & $0.693^{* * *}$ & $0.124^{* * *}$ & $0.119^{* * *}$ & 0.000 & 0.009 \\
\hline & $(0.0000)$ & $(0.0000)$ & $(0.0000)$ & $(0.6104)$ & $(0.1203)$ & $(0.0000)$ & $(0.0000)$ & $(0.0000)$ & $(0.7552)$ & $(0.0979)$ & $(0.0000)$ & $(0.0000)$ & $(0.0000)$ & $(0.9778)$ & $(0.5577)$ \\
\hline \multirow[t]{2}{*}{ Q4 } & $1.934 * * *$ & $0.199^{* * *}$ & $0.173^{* * *}$ & 0.000 & 0.088 & $1.286^{* * * *}$ & $0.164^{* * * *}$ & $0.133^{* * * *}$ & -0.000 & 0.062 & $0.683^{* * * *}$ & $0.090^{* * *}$ & $0.072^{* * *}$ & -0.000 & 0.018 \\
\hline & $(0.0000)$ & $(0.0003)$ & $(0.0009)$ & $(0.5380)$ & $(0.1956)$ & $(0.0000)$ & $(0.0000)$ & $(0.0001)$ & $(0.9458)$ & $(0.1628)$ & $(0.0000)$ & $(0.0000)$ & $(0.0002)$ & $(0.2776)$ & $(0.4739)$ \\
\hline Q5 & $1.988^{* * *}$ & $0.336^{* * *}$ & $0.335^{* * *}$ & -0.000 & $0.119^{* *}$ & $1.371^{* * *}$ & $0.239^{* * *}$ & $0.237^{* * *}$ & $-0.000^{*}$ & $0.072^{* *}$ & $0.736^{* * *}$ & $0.101^{* * *}$ & $0.104^{* * *}$ & $-0.000^{*}$ & 0.015 \\
\hline
\end{tabular}

\begin{tabular}{|c|c|c|c|c|c|c|c|c|c|c|c|c|c|c|c|}
\hline \multicolumn{16}{|c|}{ Panel B: Quintile Regressions by Officesize2 } \\
\hline & \multicolumn{5}{|c|}{ FUTCF3 } & \multicolumn{5}{|c|}{ FUTCF2 } & \multicolumn{5}{|c|}{ FUTCF1 } \\
\hline & OANCF & DA & NDA & $\begin{array}{c}\text { PERC } \\
\text { GROWTH }\end{array}$ & CONSTANT & OANCF & DA & NDA & $\begin{array}{c}\text { PERC } \\
\text { GROWTH }\end{array}$ & CONSTANT & OANCF & DA & NDA & $\begin{array}{c}\text { PERC } \\
\text { GROWTH }\end{array}$ & CONSTANT \\
\hline \multirow[t]{2}{*}{ Q1 } & $1.973 * * *$ & $0.467 * * *$ & $0.484 * * *$ & -0.000 & $0.156^{* *}$ & $1.319^{* * * *}$ & $0.300^{* * *}$ & $0.307 * * *$ & -0.000 & $0.103^{* *}$ & $0.687^{* * * *}$ & $0.164 * * *$ & $0.172^{* * *}$ & 0.000 & 0.023 \\
\hline & $(0.0000)$ & $(0.0000)$ & $(0.0000)$ & $(0.4741)$ & $(0.0179)$ & $(0.0000)$ & $(0.0000)$ & $(0.0000)$ & $(0.5206)$ & $(0.0119)$ & $(0.0000)$ & $(0.0000)$ & $(0.0000)$ & $(0.9914)$ & $(0.3088)$ \\
\hline \multirow[t]{2}{*}{ Q2 } & $2.129^{* * *}$ & $0.330^{* * *}$ & $0.262^{* * *}$ & 0.000 & $0.103^{* *}$ & $1.421^{* * *}$ & $0.212^{* * *}$ & $0.175^{* * *}$ & 0.000 & $0.067^{* *}$ & $0.714^{* * *}$ & $0.119^{* * *}$ & $0.110^{* * *}$ & 0.000 & 0.016 \\
\hline & $(0.0000)$ & $(0.0000)$ & $(0.0001)$ & $(0.1578)$ & $(0.0452)$ & $(0.0000)$ & $(0.0000)$ & $(0.0001)$ & $(0.3349)$ & $(0.0470)$ & $(0.0000)$ & $(0.0000)$ & $(0.0000)$ & $(0.7057)$ & $(0.3813)$ \\
\hline \multirow[t]{2}{*}{ Q3 } & $2.061^{* * *}$ & $0.173 * * *$ & $0.223^{* * *}$ & -0.000 & $0.136^{* *}$ & $1.354^{* * * *}$ & $0.131^{* * *}$ & $0.161^{* * *}$ & -0.000 & $0.099 * * *$ & $0.707^{* * * *}$ & $0.060^{* * *}$ & $0.076^{* * * *}$ & -0.000 & $0.035^{*}$ \\
\hline & $(0.0000)$ & $(0.0009)$ & $(0.0000)$ & $(0.4860)$ & $(0.0139)$ & $(0.0000)$ & $(0.0001)$ & $(0.0000)$ & $(0.2087)$ & $(0.0051)$ & $(0.0000)$ & $(0.0006)$ & $(0.0000)$ & $(0.1254)$ & $(0.0589)$ \\
\hline \multirow[t]{2}{*}{ Q4 } & $1.999^{* * *}$ & $0.310^{* * *}$ & $0.271^{* * *}$ & -0.000 & $0.106^{* * *}$ & $1.369^{* * *}$ & $0.237^{* * *}$ & $0.195^{* * *}$ & $-0.000^{* *}$ & $0.068^{* * * *}$ & $0.722^{* * *}$ & $0.117^{* * *}$ & $0.087^{* * *}$ & $-0.000^{*}$ & 0.018 \\
\hline & $(0.0000)$ & $(0.0000)$ & $(0.0000)$ & $(0.2330)$ & $(0.0051)$ & $(0.0000)$ & $(0.0000)$ & $(0.0000)$ & $(0.0427)$ & $(0.0063)$ & $(0.0000)$ & $(0.0000)$ & $(0.0000)$ & $(0.0635)$ & $(0.1873)$ \\
\hline Q5 & $1.913^{* * *}$ & $0.411^{* * * *}$ & $0.405^{* * *}$ & -0.000 & $0.109 * * *$ & $1.286^{* * *}$ & $0.304 * * *$ & $0.308^{* * *}$ & $-0.000^{*}$ & $0.066^{* * * *}$ & $0.690^{* * *}$ & $0.142^{* * *}$ & $0.154^{* * *}$ & $-0.000^{*}$ & 0.013 \\
\hline
\end{tabular}

Table 6 presents the results of regressions of future cash flows from operations, accumulated over 1, 2, or 3 fiscal years into the future,

on current period earnings components, by OFFICESIZE portfolio. The portfolios are assembled based on an observation's quintile of OFFICESIZE.

Table 6 presents the results by dependent variable (1, 2, or 3 annual future cash flows from operations). Within each dependent variable category the results are also separated by OFFICESIZE portfolio. Panel A presents the results when using OFFICESIZE1 as the proxy for OFFICESIZE.

Panel B presents the results when using OFFICESIZE2 as the proxy for OFFICESIZE.

Variables are as defined in Table 2.

$* * *, * *, *$ denote significance at the $0.01,0.05$, and 0.10 levels, respectively. P-values are represented in parentheses. 
Panel B of Table 6 presents the results when OFFICESIZE2 is used to determine the portfolio subsamples. Again, the coefficients on OANCF, DA, and NDA are significantly positive across all quintiles of OFFICESIZE2 and across all dependent variable specifications. The relationship between future cash flow from operations and both current DA and current NDA appear to be U-shaped in OFFICESIZE2. This relation is more clearly shown when partitioning the sample on OFFICESIZE2 than when using OFFICESIZE1. In each dependent variable specification there is a monotonic decline in the coefficients on DA and NDA as one moves from the first to the third quintile of OFFICESIZE2. There is also a monotonic increase in the coefficient on DA and NDA as one moves from the third quintile to the fifth quintile of OFFICESIZE2. In untabulated tests, the significance is tested for both the decline in coefficient values on DA and NDA from quintile 1 to quintile 3, and the increase in coefficient values on DA and NDA from quintile 3 to quintile 5 . In each case both the declines and the increases were significant at the $5 \%$ level or better.

Table 7 presents the results of portfolio regressions of accumulated future income values on current period earnings components. Panel A presents the results when OFFICESIZE1 is used to partition the sample. Each of the coefficients on OANCF, DA, and NDA is significantly positive across each of the quintiles of OFFICESIZE1 and across each of the dependent variable specifications. Further, the coefficients on both DA and NDA appear to demonstrate a slightly right-shifted U-shaped relation with OFFICESIZE1. It appears the relations between future cash flow from operations and both DA and NDA are declining in OFFICESIZE between quintile 1 and quintile 4, and the relation increases from quintile 4 to quintile 5. This appears to be the case for all specifications for NDA and all but one specification for DA. Additionally, the significance was tested on the decline in coefficient values for DA and NDA from quintile 1 to quintile 4 and the increase in coefficient values from quintile 4 to quintile 5. The coefficient decreases were all significant at the $1 \%$ level. However, none of the coefficient increases were significant at the $10 \%$ or better level.

Panel B of Table 7 presents the results when OFFICESIZE2 is used. Again, the coefficients on OANCF, DA, and NDA are significantly positive across all quintiles of OFFICESIZE2 and across all dependent variable specifications. The relations between future income values and both current DA and current NDA appear to be U-shaped in OFFICESIZE2. These relations demonstrate the same familiar U-shaped pattern observed in the previous Panels. Again, the decline in coefficient values were tested on DA and NDA from quintile 1 to quintile 3 . The declines were significant at the $1 \%$ levels in all cases. However, the increases were significant at the $10 \%$ level or higher for only those specifications using either FUTNI1 and FUTNI3.

\section{Conclusions}

This study examines the differential informativeness of components of current earnings between clients using auditors from small versus large offices within the Big 4. Prior literature finds that auditors from larger offices exhibit more constraint on client earnings management than do their smaller office counterparts. These prior studies did not investigate the differential earnings informativeness that results from clients utilizing an auditor from a larger versus a smaller office. Some evidence is found that the informativeness of current period accruals (both discretionary and nondiscretionary components) is U-shaped in the size of the auditor's office. That is, the informativeness of accruals declines in the size of the auditor's office, to a point, and then makes a slight improvement as ones move from medium to large sized offices.

Such evidence is consistent with both costs and benefits of an auditor's office size affecting the informativeness of earnings. The primary costs are the excessive concern about reputation loss and the capacity stress. These costs likely impair the auditor's judgments regarding whether earnings management is done for opportunistic or informative reasons. Without the ability to separate the two types of earnings management, the auditor likely becomes overly cautious about accruals, encouraging management to exclude both informative and opportunistic accruals. These costs to auditor judgment are likely increasing in the size of the auditor's office. The benefit of using an auditor from a larger office, however, is their access to greater levels of local area audit expertise. This improved access is likely to allow auditors to better differentiate between opportunistic and informative accruals, thus allowing management the ability to report using informative accruals while constraining opportunistic accruals. This benefit is also likely to increase in the size of the auditor's office. 
Table 7. Partitioned Regressions for Future Net Income

$$
\text { FUTNI }_{j t+1 \text { to } j+n}=\Psi_{0}+\Psi_{1} \mathrm{OANCF}_{j t}+\Psi_{2} \mathrm{DA}_{j t}+\Psi_{3} \mathrm{ND} A_{j t}+\Psi_{4} \mathrm{OFFICESIZE}_{j t}+\Psi_{8} \mathrm{GROWTH}_{j t}+\pi_{j t}
$$

\begin{tabular}{|c|c|c|c|c|c|c|c|c|c|c|c|c|c|c|c|}
\hline \multicolumn{6}{|c|}{$\begin{array}{l}\text { Panel A: Quintile Regressions by Officesize1 } \\
\text { FUTNI3 }\end{array}$} & \multicolumn{5}{|c|}{ FUTNI2 } & \multicolumn{5}{|c|}{ FUTNI1 } \\
\hline & OANCF & DA & NDA & $\begin{array}{c}\text { PERC } \\
\text { GROWTH }\end{array}$ & CONSTANT & OANCF & DA & $\mathrm{NDA}$ & $\begin{array}{c}\text { PERC } \\
\text { GROWTH }\end{array}$ & CONSTANT & OANCF & DA & $\mathrm{NDA}$ & $\begin{array}{c}\text { PERC } \\
\text { GROWTH }\end{array}$ & CONSTANT \\
\hline Q1 & $\begin{array}{l}2.040^{* * *} \\
(0.0000)\end{array}$ & $\begin{array}{c}0.909^{* * * *} \\
(0.0000)\end{array}$ & $\begin{array}{c}0.953^{* * * *} \\
(0.0000)\end{array}$ & $\begin{array}{c}-0.001 * * * \\
(0.0005)\end{array}$ & $\begin{array}{l}-0.077 * \\
(0.0554)\end{array}$ & $\begin{array}{c}1.372^{* * *} \\
(0.0000)\end{array}$ & $\begin{array}{l}0.590^{* * * *} \\
(0.0000)\end{array}$ & $\begin{array}{l}0.606^{* * *} \\
(0.0000)\end{array}$ & $\begin{array}{c}-0.000 * * * \\
(0.0096)\end{array}$ & $\begin{array}{c}-0.096^{* * *} \\
(0.0001)\end{array}$ & $\begin{array}{c}0.719 * * * \\
(0.0000)\end{array}$ & $\begin{array}{l}0.299^{* * *} \\
(0.0000)\end{array}$ & $\begin{array}{l}0.309 * * * \\
(0.0000)\end{array}$ & $\begin{array}{c}-0.000^{* *} \\
(0.0441)\end{array}$ & $\begin{array}{c}-0.076^{* * *} \\
(0.0000)\end{array}$ \\
\hline Q2 & $\begin{array}{c}2.399 * * * \\
(0.0000)\end{array}$ & $\begin{array}{c}0.872 * * * \\
(0.0000)\end{array}$ & $\begin{array}{c}0.889^{* * *} \\
(0.0000)\end{array}$ & $\begin{array}{l}-0.000^{*} \\
(0.0703)\end{array}$ & $\begin{array}{l}-0.131^{* *} \\
(0.0167)\end{array}$ & $\begin{array}{l}1.547^{* * *} \\
(0.0000)\end{array}$ & $\begin{array}{l}0.583^{* * *} \\
(0.0000)\end{array}$ & $\begin{array}{c}0.608^{* * *} \\
(0.0000)\end{array}$ & $\begin{array}{c}-0.000 \\
(0.5746)\end{array}$ & $\begin{array}{c}-0.124 * * * \\
(0.0004)\end{array}$ & $\begin{array}{l}0.806 * * * \\
(0.0000)\end{array}$ & $\begin{array}{c}0.286^{* * *} \\
(0.0000)\end{array}$ & $\begin{array}{l}0.307^{* * *} \\
(0.0000)\end{array}$ & $\begin{array}{c}-0.000 \\
(0.5349)\end{array}$ & $\begin{array}{c}-0.082 * * * \\
(0.0000)\end{array}$ \\
\hline Q3 & $\begin{array}{c}2.272^{* * *} \\
(0.0000)\end{array}$ & $\begin{array}{c}0.698^{* * *} \\
(0.0000)\end{array}$ & $\begin{array}{c}0.657^{* * *} \\
(0.0000)\end{array}$ & $\begin{array}{c}-0.000 \\
(0.1877)\end{array}$ & $\begin{array}{l}-0.230 * * * \\
(0.0000)\end{array}$ & $\begin{array}{c}1.521^{* * *} \\
(0.0000)\end{array}$ & $\begin{array}{l}0.441^{* * *} \\
(0.0000)\end{array}$ & $\begin{array}{c}0.414 * * * \\
(0.0000)\end{array}$ & $\begin{array}{c}-0.000 \\
(0.2571)\end{array}$ & $\begin{array}{c}-0.195^{* * *} \\
(0.0000)\end{array}$ & $\begin{array}{c}0.736^{* * *} \\
(0.0000)\end{array}$ & $\begin{array}{l}0.262^{* * *} \\
(0.0000)\end{array}$ & $\begin{array}{c}0.254^{* * *} \\
(0.0000)\end{array}$ & $\begin{array}{c}0.000 \\
(0.2704)\end{array}$ & $\begin{array}{c}-0.126^{* * *} \\
(0.0000)\end{array}$ \\
\hline Q4 & $\begin{array}{l}2.168^{* * *} \\
(0.0000)\end{array}$ & $\begin{array}{c}0.340^{* * *} \\
(0.0000)\end{array}$ & $\begin{array}{c}0.348^{* * *} \\
(0.0000)\end{array}$ & $\begin{array}{l}-0.000^{*} \\
(0.0871)\end{array}$ & $\begin{array}{l}-0.146^{*} \\
(0.0804)\end{array}$ & $\begin{array}{c}1.468^{* * *} \\
(0.0000)\end{array}$ & $\begin{array}{l}0.267^{* * *} \\
(0.0000)\end{array}$ & $\begin{array}{l}0.252^{* * *} \\
(0.0000)\end{array}$ & $\begin{array}{l}-0.000 * \\
(0.0702)\end{array}$ & $\begin{array}{l}-0.101^{*} \\
(0.0503)\end{array}$ & $\begin{array}{c}0.799 * * * \\
(0.0000)\end{array}$ & $\begin{array}{l}0.154^{* * * *} \\
(0.0000)\end{array}$ & $\begin{array}{l}0.137^{* * *} \\
(0.0000)\end{array}$ & $\begin{array}{c}-0.000 \\
(0.1762)\end{array}$ & $\begin{array}{c}-0.080 * * * \\
(0.0097)\end{array}$ \\
\hline
\end{tabular}

\begin{tabular}{|c|c|c|c|c|c|c|c|c|c|c|c|c|c|c|c|}
\hline \multicolumn{16}{|c|}{ Panel B: Quintile Regressions by Officesize2 } \\
\hline & \multicolumn{5}{|c|}{ FUTCF3 } & \multicolumn{5}{|c|}{ FUTCF2 } & \multicolumn{5}{|c|}{ FUTCF1 } \\
\hline & OANCF & DA & NDA & $\begin{array}{c}\text { PERC } \\
\text { GROWTH } \\
\end{array}$ & CONSTANT & OANCF & DA & NDA & $\begin{array}{c}\text { PERC } \\
\text { GROWTH }\end{array}$ & CONSTANT & OANCF & $\mathrm{DA}$ & NDA & $\begin{array}{c}\text { PERC } \\
\text { GROWTH }\end{array}$ & CONSTANT \\
\hline \multirow[t]{2}{*}{ Q1 } & $2.143^{* * *}$ & $1.007^{* * *}$ & $1.040^{* * *}$ & -0.000 & -0.109 & $1.431^{* * *}$ & $0.635^{* * *}$ & $0.650^{* * *}$ & 0.000 & $-0.133^{* * *}$ & $0.749 * * *$ & $0.327^{* * *}$ & $0.343^{* * *}$ & 0.000 & $-0.104^{* * *}$ \\
\hline & $(0.0000)$ & $(0.0000)$ & $(0.0000)$ & $(0.1163)$ & $(0.1485)$ & $(0.0000)$ & $(0.0000)$ & $(0.0000)$ & $(0.9723)$ & $(0.0043)$ & $(0.0000)$ & $(0.0000)$ & $(0.0000)$ & $(0.4559)$ & $(0.0001)$ \\
\hline \multirow[t]{2}{*}{ Q2 } & $2.361^{* * *}$ & $0.777^{* * *}$ & $0.725^{* * *}$ & -0.000 & $-0.125^{* *}$ & $1.538^{* * *}$ & $0.499 * * *$ & $0.472 * * *$ & -0.000 & $-0.119^{* * *}$ & $0.785^{* * *}$ & $0.239^{* * *}$ & $0.236^{* * *}$ & 0.000 & $-0.080^{* * *}$ \\
\hline & $(0.0000)$ & $(0.0000)$ & $(0.0000)$ & $(0.8212)$ & $(0.0405)$ & $(0.0000)$ & $(0.0000)$ & $(0.0000)$ & $(0.7721)$ & $(0.0033)$ & $(0.0000)$ & $(0.0000)$ & $(0.0000)$ & $(0.5732)$ & $(0.0003)$ \\
\hline \multirow[t]{2}{*}{ Q3 } & $2.283^{* * *}$ & $0.359 * * *$ & $0.413^{* * *}$ & $-0.001^{* * *}$ & -0.103 & $1.501^{* * *}$ & $0.265^{* * *}$ & $0.291 * * *$ & $-0.001^{* * *}$ & $-0.090^{* *}$ & $0.789^{* * * *}$ & $0.145^{* * * *}$ & $0.159^{* * *}$ & $-0.000^{* *}$ & $-0.063^{* * * *}$ \\
\hline & $(0.0000)$ & $(0.0000)$ & $(0.0000)$ & $(0.0045)$ & $(0.1223)$ & $(0.0000)$ & $(0.0000)$ & $(0.0000)$ & $(0.0006)$ & $(0.0314)$ & $(0.0000)$ & $(0.0000)$ & $(0.0000)$ & $(0.0274)$ & $(0.0061)$ \\
\hline \multirow[t]{2}{*}{ Q4 } & $2.179^{* * *}$ & $0.476^{* * *}$ & $0.450^{* * *}$ & $-0.001 * *$ & $-0.149^{* * *}$ & $1.507^{* * *}$ & $0.336^{* * *}$ & $0.306^{* * *}$ & $-0.000^{* * *}$ & $-0.129^{* * *}$ & $0.801 * * *$ & $0.184^{* * *}$ & $0.158^{* * *}$ & $-0.000^{*}$ & $-0.094^{* * *}$ \\
\hline & $(0.0000)$ & $(0.0000)$ & $(0.0000)$ & $(0.0110)$ & $(0.0009)$ & $(0.0000)$ & $(0.0000)$ & $(0.0000)$ & $(0.0071)$ & $(0.0000)$ & $(0.0000)$ & $(0.0000)$ & $(0.0000)$ & $(0.0596)$ & $(0.0000)$ \\
\hline Q5 & $(0.0000)$ & $(0.0000)$ & $(0.0000)$ & $(0.0001)$ & $(0.0000)$ & $(0.0000)$ & $(0.0000)$ & $(0.0000)$ & $(0.0011)$ & $(0.0000)$ & $(0.0000)$ & $(0.0000)$ & $(0.0000)$ & $(0.0223)$ & $(0.0000)$ \\
\hline
\end{tabular}

Table 7 presents the results of regressions of future income values, accumulated over 1, 2, or 3 fiscal years into the future,

on current period earnings components, by OFFICESIZE portfolio. The portfolios are assembled based on an observation's quintile of OFFICESIZE.

Table 7 presents the results by dependent variable (1, 2, or 3 annual future income values). Within each dependent variable category the results are also separated by OFFICESIZE portfolio. Panel A presents the results when using OFFICESIZE1 as the proxy for OFFICESIZE.

Panel B presents the results when using OFFICESIZE2 as the proxy for OFFICESIZE.

Variables are as defined in Table 2.

$* * *, * *, *$ denote significance at the $0.01,0.05$, and 0.10 levels, respectively. P-values are represented in parentheses.

The U-shaped relation between the informativeness of accruals and the size of the auditor's office can be interpreted as evidence of the competing influence on the informativeness of accruals between the costs and the benefits of auditor office size. It appears that, at least initially, the impact of the auditor's concerns about reputation damage and auditor capacity stress increase rapidly in the size of the auditor's office. The impact of a change in the availability of local area audit expertise, however, may be small until the auditor's office is sufficiently large. This may be because either there is little difference in local area audit expertise between auditors from small and medium sized offices or because the impact of an additional unit of local area audit expertise is smaller than the impact of an additional unit of auditor reputation concern and capacity stress when the auditor's office is small to medium sized. Either condition would explain the U-shaped relation found in this study. 
These results are useful to several groups. First, academics may be interested in these findings because they extend prior audit quality literature. Second, regulators, such as the PCAOB, may find value in these results because it is their job to ensure audits yield earnings that are beneficial to investors and other users of financial statements. Lastly, investors may be interested in these conclusions because investors are the end users of financial statements, and indicators of higher quality financial statements can better guide their pricing and investment decisions.

\section{References}

Altamuro, J., Beatty, A., \& Weber, J. (2005). The Effects of Accelerated Revenue Recognition on Earnings Management and Earnings Informativeness: Evidence From SEC Staff Accounting Bulletin No. 101. The Accounting Review (80): p. 373. http://dx.doi.org/10.2308/accr.2005.80.2.373

Balsam, S.; Krishnan, J.; \& Yang, J. (2003). Auditor Industry Specialization and Earnings Quality. Auditing: A Journal of Practice and Theory (September): p. 1.

Becker, C.; Defond, M.; Jiambalvo, J.; \& Subramanyam, K.R. 1998. The Effect of Audit Quality on Earnings Management. Contemporary Accounting Research (Spring): $\quad$ p. 1. http://dx.doi.org/10.1111/j.1911-3846.1998.tb00547.x

Boone, J. P., I. K. Khurana, \& K. K. Raman. (2010). Do the Big 4 and the Second-tier firms provide audits of similar quality? Journal of Accounting and Public Policy 29: 330-352. http://dx.doi.org/10.1016/j.jaccpubpol.2010.06.007

Burgstahler, D. \& Dichev, I. (1997). Earnings Management to Avoid Earnings Decreases and Losses. Journal of Accounting and Economics (24): p. 99. http://dx.doi.org/10.1016/S0165-4101(97)00017-7

Buslepp, W. \&Victoravich, L. (2011). working paper. Firms that Fail to Address PCAOB Quality Control Criticisms Satisfactorily: New Insights on Audit Quality and Going Concern Reports

Carcello, J., \& Z. Palmrose. (1994). Auditor litigation and modified reporting on bankrupt clients. Journal of Accounting Research (32 supplement):1-30. http://dx.doi.org/10.2307/2491436

Choi, J. Kim, C., Kim, J., \& Zang, J. (2010). Audit Office Size, Audit Quality, and Audit Pricing. Auditing: $A$ Journal of Practice and Theory (29): p. 73-97.

Davidson, R. \& Neu, D. (1993). A Note on the Association Between Audit Firm Size and Audit Quality. Contemporary Accounting Research (9): p. 479. http://dx.doi.org/10.1111/j.1911-3846.1993.tb00893.x

DeAngelo, L. (1981). Auditor Size and Auditor Quality. Journal of Accounting and Economics. (3): pps 183-199.

Dechow, P. (1994). Accounting Earnings and Cash Flows as Measures of Firm Performance. The Role of Accounting Accruals. Journal of Accounting and Economics (18): p. 3. http://dx.doi.org/10.1016/0165-4101(94)90016-7

DeFond, M. \& Jiambalvo, J. (1991). Incidence and Circumstances of Accounting Errors. The Accounting Review (June): p. 643.

DeFond, M. \& Jiambalvo, J. (1994). Debt Covenant Violation and Manipulation of Accruals. Journal of Accounting and Economics (17): p. 145. http://dx.doi.org/10.1016/0165-4101(94)90008-6

Doyle, J., Lundholm, R., \& Soliman, M. (2003). The Predictive Value of Expenses Excluded From Pro Form Earnings. Review of Accounting Studies (8): p. 145. http://dx.doi.org/10.1023/A:1024472210359

Financial Accounting Standards Board (FASB). (1978). Objectives of Financial Reporting by Business Enterprises. Statement of Financial Accounting Concepts No. 1. Norwalk, CT: FASB.

Francis, J. \& Yu, D. (2009). Big 4 Office Size and Audit Quality. The Accounting Review (84): 1521-1552. http://dx.doi.org/10.2308/accr.2009.84.5.1521

Guay, W., Kothari, S.P., \& Watts, R. (1996). A Market-Based Evaluation of Discretionary Accruals Models. Journal of Accounting Research (34): p. 83. http://dx.doi.org/10.2307/2491427

Hansen, S.; Kumar, K.; \& Sullivan, M. (2008). working paper. Auditor Capacity Stress and Audit Quality: Market-Based Evidence from Anderson's Indictment.

Healy, P. (1985). The Effect of Bonus Schemes on Accounting Decisions. Journal of Accounting and Economics (April): p. 85. http://dx.doi.org/10.1016/0165-4101(85)90029-1 
Jones, J. (1991). Earnings Management During Import Relief Investigations. Journal of Accounting Research (Autumn): p. 193. http://dx.doi.org/10.2307/2491047

Kothari, S. P., A. Leone, \& C. Wasley. (2005). Performance matched discretionary accruals. Journal of Accounting and Economics 39 (1): 163-197. http://dx.doi.org/10.1016/j.jacceco.2004.11.002

Krishnan, G. 2003. Audit Quality and the Pricing of Discretionary Accruals. Auditing (22): p. 109.

Louis, H. \& Robinson, D. (2005). Do Managers Credibly Use Accruals to Signal Private Information? Evidence From the Pricing of Discretionary Accruals Around Stock Splits. Journal of Accounting and Economics (39): p. 361. http://dx.doi.org/10.1016/j.jacceco.2004.07.004

Mascarenhas, D., Cahan, S., \& Naiker, V. (2010). The Effect of Audit Specialists on the Informativeness of Discretionary Accruals. Journal of Accounting Auditing and Finance (25): p. 53.

Palmrose, Z. V. (1988). An Analysis of Auditor Litigation and Audit Service Quality. The Accounting Review (January): p. 55.

Subramanyam, K.R. (1996). The Pricing of Discretionary Accruals. The Journal of Accounting and Economics (22): p. 249. http://dx.doi.org/10.1016/S0165-4101(96)00434-X

Titman, S. \& Trueman, B. (1986). Information Quality and the Valuation of New Issues. Journal of Accounting and Economics (8): p. 159. http://dx.doi.org/10.1016/0165-4101(86)90016-9

Wallace, W. (1980). The Economic Role of the Audit in Free and Regulated Markets. Touche Ross and Co. Aid to Education Program.

Watkins, A., Hillison, W., \& Morecroft, S. (2004). Audit Quality: A Synthesis of Theory and Empirical Evidence. Journal of Accounting Literature (23): p. 153. 